\title{
REVIEW
}

\section{Escapes of fishes from Norwegian sea-cage aquaculture: causes, consequences and prevention}

\author{
Ø. Jensen ${ }^{1}$, T. Dempster ${ }^{1,2, *}$, E. B. Thorstad ${ }^{3}$, I. Uglem $^{3}$, A. Fredheim ${ }^{1}$ \\ ${ }^{1}$ Centre for Research-based Innovation in Aquaculture Technology (CREATE), SINTEF Fisheries and Aquaculture, \\ 7465 Trondheim, Norway \\ ${ }^{2}$ Department of Zoology, University of Melbourne, Victoria 3010, Australia \\ ${ }^{3}$ Norwegian Institute for Nature Research, 7485 Trondheim, Norway
}

\begin{abstract}
The escape of fish from aquaculture is perceived as a threat to wild fish populations. The escapes problem is largely caused by technical and operational failures of fish farming equipment. In Norway, 3.93 million Atlantic salmon Salmo salar, 0.98 million rainbow trout Oncorhynchus mykiss and 1.05 million Atlantic cod Gadus morhua escaped from 2001 to 2009. Salmonids primarily escape after structural failures of containment equipment, while a far greater percentage of cod than salmon escape through holes in the nets. Correlative evidence suggests that after the Norwegian technical standard (NS 9415) for sea-cage farms took effect in 2004, the total number of escaped Atlantic salmon declined from $>600000$ (2001 to 2006) to <200000 fish $\mathrm{yr}^{-1}$ (2007 to 2009), despite the total number of salmon held in sea-cages increasing by $44 \%$ during this period. No similar decrease in escaped cod has occurred, suggesting that other measures, such as improved netting materials for sea-cages, are required. In addition to escaping as juveniles or adults, cod may reproduce in seacages, and thus fertilised eggs escape to the environment. The ecological effects of 'escape through spawning' are unclear, and methods to inhibit escape by this mechanism are being explored. To prevent escapes of juvenile and adult fish as sea-cage aquaculture industries develop, we recommend that policy-makers implement a 5 component strategy: (1) establish mandatory reporting of all escape incidents; (2) establish a mechanism to analyse and learn from the mandatory reporting; (3) conduct mandatory, rapid, technical assessments to determine the causes of escape incidents involving more than $10000 \mathrm{fish}_{\text {; }}$ (4) introduce a technical standard for sea-cage aquaculture equipment coupled with an independent mechanism to enforce the standard; and (5) conduct mandatory training of fish farm staff in escape-critical operations and techniques.
\end{abstract}

KEY WORDS: Salmonids · Cod · Technology · Regulation · Standard · Competition · Disease · Interbreeding $\cdot$ Fish farming

\section{INTRODUCTION}

\section{Definition of escapes from aquaculture}

Escapes of fish from sea-cage aquaculture have typically been thought of as referring to juvenile and adult fish. Such escapes have been reported for almost all species presently cultured around the world, including Atlantic salmon Salmo salar, Atlantic cod Gadus morhua, rainbow trout Oncorhynchus mykiss, Arctic charr Salvelinus alpinus, halibut Hippoglossus hippoglossus, sea bream Sparus aurata, sea bass Dicentrachus labrax, meagre Angyrosomus regius and kingfish Seriola lalandi (e.g. Soto et al. 2001, Naylor et al. 2005, Gillanders \& Joyce 2005, Moe et al. 2007a, Toledo Guedes et al. 2009). Recently, a second form of escape has come into focus, involving the escape of viable, fertilised eggs spawned by farmed individuals from sea- 
cage facilities, or so-called 'escape through spawning' (Jørstad et al. 2008). This phenomenon has forced a redefinition of the term 'escapes from aquaculture' to include the escapement of fertilised eggs into the wider marine environment.

\section{Review scope}

Here, we document the current status of knowledge on the extent and causes of escapes, provide a short summary of their economic and environmental consequences, and discuss measures to prevent escapes. We address both escapes of juvenile/larger fish and escape through spawning. As most of the research and development on the escapes issue over the past 2 decades has been related to the Norwegian fish farming industry, we use Norway as a case study to describe the development and implementation of measures to deal with escapes. Finally, we provide a series of recommendations for policy makers to implement measures to prevent escapes as sea-cage aquaculture industries develop in other countries.

\section{Background: the Norwegian fish farming industry}

The Norwegian marine aquaculture industry, which commenced in 1969-1970, is widely considered a commercial success story. Today, Norway is a world leader in the culture of salmon in sea-cages; 582 farms operated in coastal waters in 2008 and produced $797000 \mathrm{t}$ of Atlantic salmon and $92000 \mathrm{t}$ of rainbow trout (Kjønhaug 2009). Approximately 310 million individual Atlantic salmon and rainbow trout were held in seacages in Norway at any given time during 2009 (Norwegian Directorate of Fisheries 2009). The Atlantic cod aquaculture industry is comparatively small and produced approximately $10000 \mathrm{t}$ across 40 farms in 2008, corresponding to 25 million fish held in the sea (Norwegian Directorate of Fisheries 2009).

\section{Farm sites}

In the early phase of sea-cage salmonid aquaculture, farm sites were located next to the shore and in very sheltered areas with little water exchange or flushing (Oppedal et al. in press). Expansion of the industry in terms of both farm number and size demanded sites with greater water exchange both to ensure good water quality for the fish and reduced impact on the benthos from the accumulation of farm wastes. Modern sites are located farther from the shore, but are still partly sheltered within bays, sounds and fjords or scattered amongst islands within archipelagos.
Sea-cage technology

Significant advances in containment technologies have been made since the industry commenced, with modern production and fish transportation systems now typically large and highly mechanised. Salmonids and cod are kept in either square or rectangular seacages of 20 to $40 \mathrm{~m}$ sides, 20 to $35 \mathrm{~m}$ deep or circles of 90 to $157 \mathrm{~m}$ in circumference and 15 to $48 \mathrm{~m}$ deep. Cage volumes range from 20000 to $80000 \mathrm{~m}^{3}$. Square cages are typically clustered together in a steel platform with between 4 and 28 cages site ${ }^{-1}$ with little distance $(2$ to $4 \mathrm{~m}$ ) between adjacent cages. Circular cages (typically 6 to 12 site $^{-1}$ ) are arranged in mooring grids in single or double rows but with typically greater space between them $(>20 \mathrm{~m})$ than square cages. Initially, cage arrangements within sites were chosen based on logistical considerations such as moorings, shelter and accessibility. Present-day cage arrangements have moved towards positioning cage grid mooring systems perpendicular to the dominant current direction to maximise water flow, oxygen supply and the removal of wastes from individual cages.

Biomasses and stocking densities

Based on the maximum allowable stocking density of $25 \mathrm{~kg} \mathrm{~m}^{-3}$ in Norway (Norwegian Ministry of Fisheries and Coastal Affairs 2008) and normal harvest weights of 4 to $5 \mathrm{~kg}$, individual cages in the 1970s held $\sim 10000$ fish. Individual cages may now contain 200000 to 400000 fish. In practice, the largest Norwegian sites produce more than $10000 \mathrm{t}$ of salmon biomass, constituting more than 2 million individual salmon. In contrast, individual cod farms are much smaller, producing 100s rather than 1000s of tons site ${ }^{-1}$.

\section{EXTENT OF ESCAPES}

Norway has the most comprehensive national record of escapes in the world; official numbers exist back to 2001 for salmonids and to 2004 for Atlantic cod. In the $9 \mathrm{yr}$ of production from 2001 to 2009, 3.93 million Atlantic salmon (436 $\left.000 \mathrm{yr}^{-1}\right)$ and 0.98 million $\left(110000 \mathrm{yr}^{-1}\right)$ rainbow trout were reported to have escaped from Norwegian farms (Fig. 1). In addition, in the 6 yr from 2004 to 2009, 1.05 million Atlantic cod $\left(175000 \mathrm{yr}^{-1}\right)$ escaped. The percentage of fish reported to escape relative to the overall numbers of fish in the sea vary greatly among these 3 species, with escape rates lowest for Atlantic salmon and highest for Atlantic cod: average escaped percentage 2001-2009 $=($ total no. escaped fish reported $) /($ esti- 

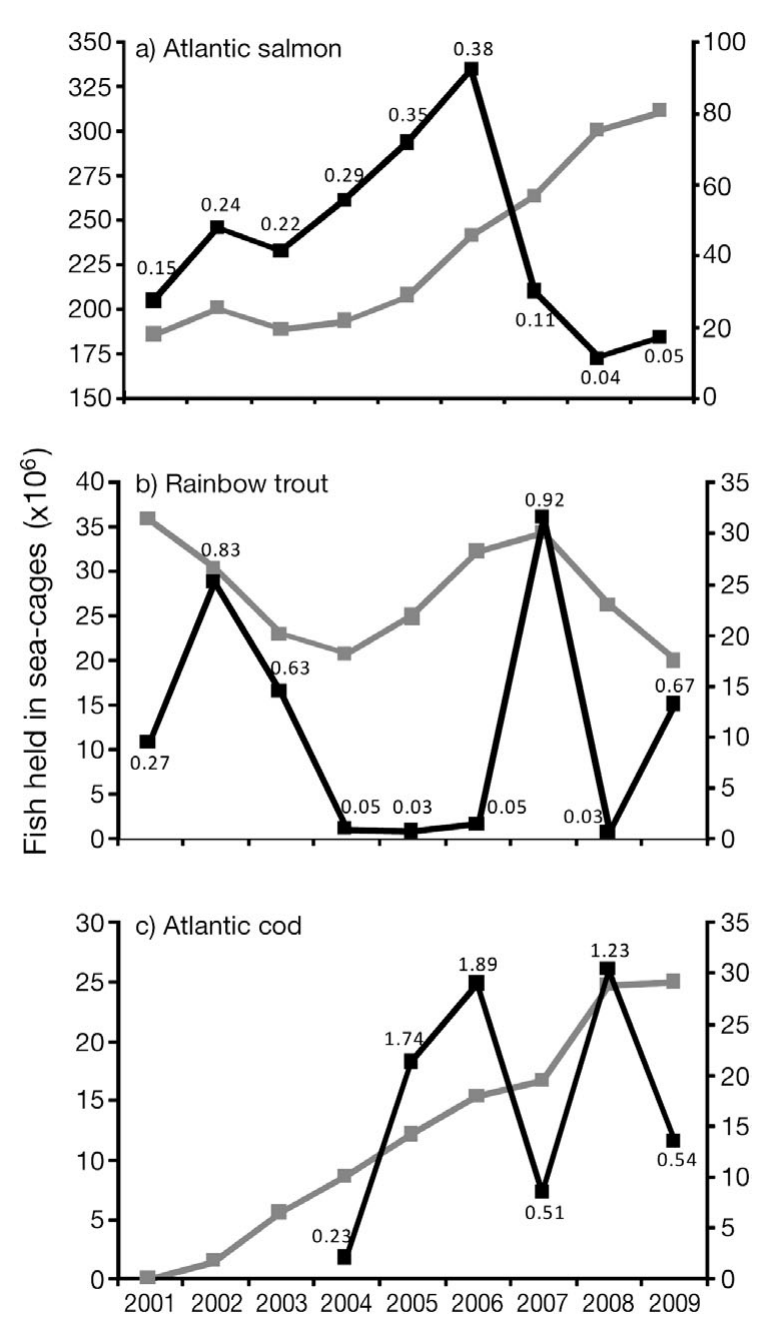

Fig. 1. Salmo salar, Oncorhynchus mykiss and Gadus morhua. Estimated numbers of cultured fish (Atlantic salmon, rainbow trout and Atlantic cod) held in sea-cages ( $\square$ ) in Norway as of 31 December each year from 2001 to 2009 and numbers of escaped fish ( $\mathbf{\square})$ reported to the Norwegian Fisheries Directorate. Numbers within each figure give the percentage of fish that escaped each year calculated from the number of reported escapees and the total estimated number of fish in the sea-cages

mated total no. fish held in sea-cages) $\times 100$; salmon: $0.19 \%$, trout $0.40 \%$, cod $1.02 \%$.

From 2005 to 2009, the number of salmonids held at individual farming locations increased industry-wide by approximately $50 \%$ (Fig. 2). As the number of fish within individual cages and individual farming sites increases, the potential consequences due to individual cage or farm breakdown increases. However, the farmers claim that with fewer units in the sea, the probability of escape events decreases. Independent of these contradicting factors regarding escape risks, the total reported number of salmon escaping from seacage farms has recently declined. Escapes of salmon

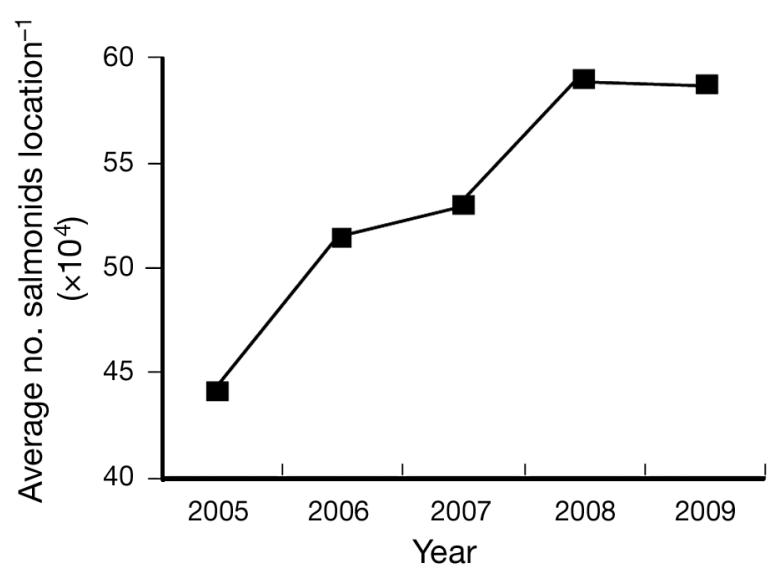

Fig. 2. Salmo salar. Average number of Atlantic salmon held per location from 2001 to 2009 based on estimated number of fish in the sea-cages and the number of sea-cage locations in operation

climbed in number (272 000 to 921000 ) and as a percentage of the total number of fish held in cages $(0.15$ to $0.38 \%$ ) from 2001 to 2006 , before declining substantially to $<200000$ fish $\mathrm{yr}^{-1}$ and $0.07 \%$ on average for 2007 to 2009 (Fig. 1). This reduction in the total number of escapees occurred despite a marked $44 \%$ increase in the total number of fish held in sea-cages in the 2007-2009 period compared to the 2001-2006 period. The marked decrease in the reported number of escapes is primarily due to a decrease in the number of large escape events involving $>10000$ fish.

For rainbow trout and Atlantic cod, trends in the total number and percentage of escaped fish over time are less clear than for Atlantic salmon (Fig. 1). As the numbers of fish in the sea for both these species are at least an order of magnitude less than salmon, the occurrence of a single large escape event can skew the escape statistics in individual years. Between 7000 and 315000 rainbow trout escaped in any given year from 2001 to 2009 , with the escape percentage varying from 0.03 to $0.92 \%$. In the year with the greatest number (315000) and highest percentage $(0.92 \%)$ of escapes, only 3 escape incidents were recorded, yet 1 of these was responsible for the loss of 300000 fish. Similarly, for cod, year to year reported escapes totalled 20000 to 304000 from 2004 to 2009, representing 0.22 to $1.89 \%$ of the fish held in sea-cages. Years with high total numbers of escaped fish were characterised by having 1 or more escape events where $>100000$ fish escaped.

Our analyses of total numbers of escaped fish and the percentage of fish that escape rely on the officially reported statistics, which have been speculated to significantly underestimate the true level of escapes (Fiske et al. 2006, Torrissen 2007), because not all escape incidents are detected and/or reported. Debate exists regarding the extent to which large-scale escape events and smaller, less detectable escape events con- 
tribute to the overall number of escaped fish. We do not address this debate in detail here; however, future studies that address this issue will provide greater perspective on the official statistics. In addition, recent advances in Norway on tracing escaped fish with genetic techniques and their subsequent successful use in court cases against farms that have not reported escapes (Glover 2010), may lead to greater detectability and an increase in the reporting of escapes in the future. Regardless of the inherent limitations of the data set, there is no reason to suggest that the sources of error in reporting have varied over time; thus the official statistics provide a solid baseline of data for comparisons across time.

\section{CAUSES OF ESCAPES}

Escapes are caused by a variety of incidents related to farming equipment and its operation. Reports by fish farming companies to the Norwegian Directorate of Fisheries following escape events during the period from September 2006 to December 2009 indicate that escapes of Atlantic salmon (by total number of fish escaped) are dominated by structural failures of equipment $(68 \%)$, with operational related-failure $(8 \%)$, escapes due to external factors (8\%) and escapes from land-based facilities (11\%) making up lesser percentages (Fig. 3). Structural failures may be generated by severe environmental forcing in strong winds, waves and currents, which may occur in combination with component fatigue or human error in the way farm

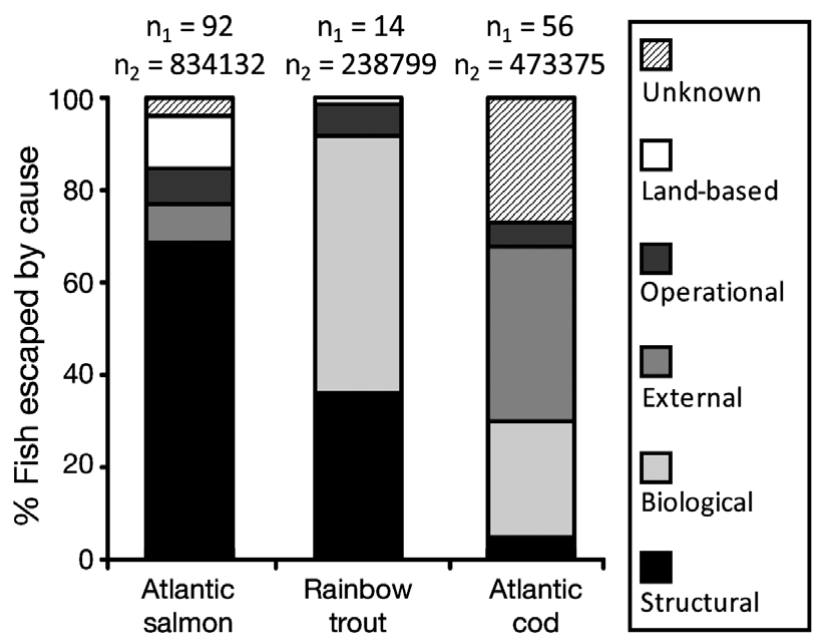

Fig. 3. Causes of escape based on reports by fish farming companies to the Norwegian Fisheries Directorate from 1 September 2006 to 31 December 2009. $\mathrm{n}_{1}$ : total number of reported escape incidents upon which the \% of fish escaped by cause is based. $\mathrm{n}_{2}$ : total number of escaped fish reported from 1 September 2006 to 31 December 2009 upon which the $\%$ of fish escaped by cause is based installations have been installed or operated (Jensen 2006). The dominance of structural failures as the main cause of escape of Atlantic salmon is also visible in the seasonal pattern of escape incidents (Fig. 4), with the greatest number of large-scale escape events ( $>10000$ individuals) occurring in the autumn months when coastal storms are most frequent and intense. For rainbow trout, structural failures accounted for $36 \%$ of escapees, while a predation event by seals at 1 farm which subsequently caused 132634 fish to escape through a net tear was the reason for the high contribution of biological causes (56\%) in this period (Fig. 3)

For cod, evidence suggests that additional reasons for escape exist beyond those present for salmonids (Moe et al. 2007a). This stems from behavioural differences in the way cod interact with cages, through biting of the netting, which may increase wear and tear and contribute to the creation of holes (Moe et al. 2007a), and a far greater level of exploratory behaviour near the net wall, which may increase the chances of cod swimming through a hole (Hansen et al. 2008). Of the 56 escape events reported from September 2006 to December 2009, external (38\%) and biological (25\%) causes accounted for the greatest numbers of escaped cod. In addition, the reason for escape was undetermined for a significant percentage of the total number of fish that escaped (27\%). In contrast to salmon, there was no specific seasonality in the occurrence of large (>10 000 individuals) or medium (1000 to 9999 individuals) escape incidents (data not shown).

Large-scale escape events of salmon, trout and cod (>10000 individuals) represented only $19 \%$ of the escape incidents reported, but accounted for $91 \%$ of the number of escaped fish (Fig. 5), indicating that a focus on preventing this small percentage of largescale incidents will have a great effect in diminishing the consequences of escapes. Structural failures, while relatively infrequent, lead to the greatest number of fish escaping (10s to 100 s of thousands of fish per incident); therefore, they are the area of greatest focus in

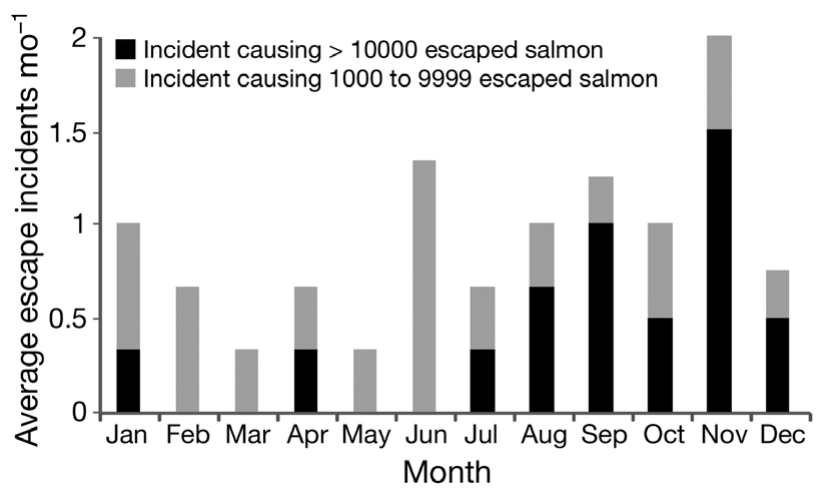

Fig. 4. Salmo salar. Seasonality of escape events for Atlantic salmon reported to the Norwegian Fisheries Directorate from 1 September 2006 to 31 December 2009 


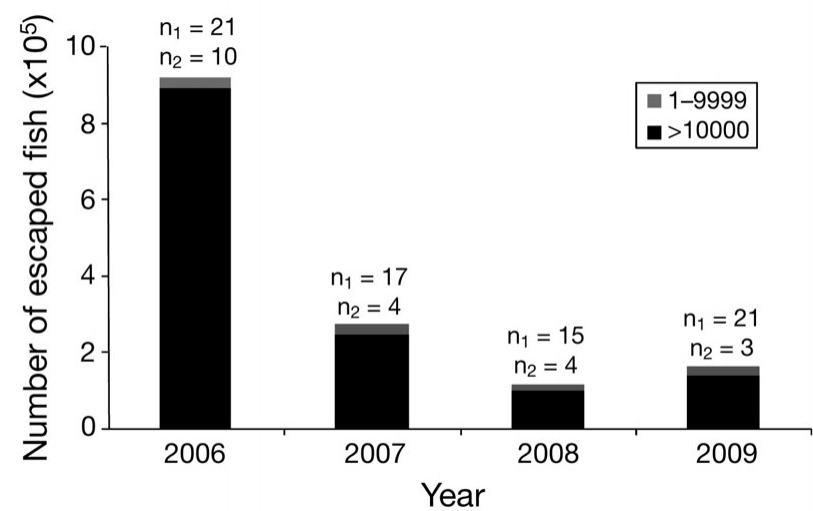

Fig. 5. Salmo salar. Numbers of Atlantic salmon escaped by size of the escape incident from 2006 to 2009. $\mathrm{n}_{1}$ : number of reported escape incidents causing 1 to 9999 fish to escape. $\mathrm{n}_{2}$ : number of reported escape incidents causing $>10000$ fish to escape

preventing escapes. Operational errors that cause escapes are more frequent, but typically lead to spills as small as a few individuals to thousands of fish, so they are of secondary importance in mitigating the escapes problem. Below, we document in detail the status of knowledge on 3 of the main causes of structural failures leading to escapes and provide examples.

\section{Progressive mooring failure}

Today, flexible circular tubes made of polyethylene are the most commonly used floating collars in Norwegian aquaculture. The major part of the flexible floating collars is moored using either a grid or a ladder mooring system. The floaters are connected to the mooring using bridles (Fredheim \& Langan 2009). Traditionally, the grid mooring system was oriented to minimise the total drag force on the fish farm, i.e. with the direction of the main current running through the length of the fish farm. Orienting the farm in this manner reduces the total drag, as only the front nets are fully exposed to the current (the subsequent ones are in the shadow of those in front and will experience a reduced current velocity). However, when the farm is oriented in this manner, the number of mooring lines in the same direction as the main current is limited. During a storm, the current velocity increases, especially in the upper water layers, exerting large forces on the nets. These forces are transferred to the mooring lines through the bridles. If 1 mooring line breaks or 1 anchor drags, the loads on the remaining mooring lines might be exceeded and they will rupture one by one, resulting in a complete failure of the fish farm (Fig. 6A). This was the cause of the complete breakdown of a fish farm in which close to 500000 salmon escaped in central Norway in August 2005.
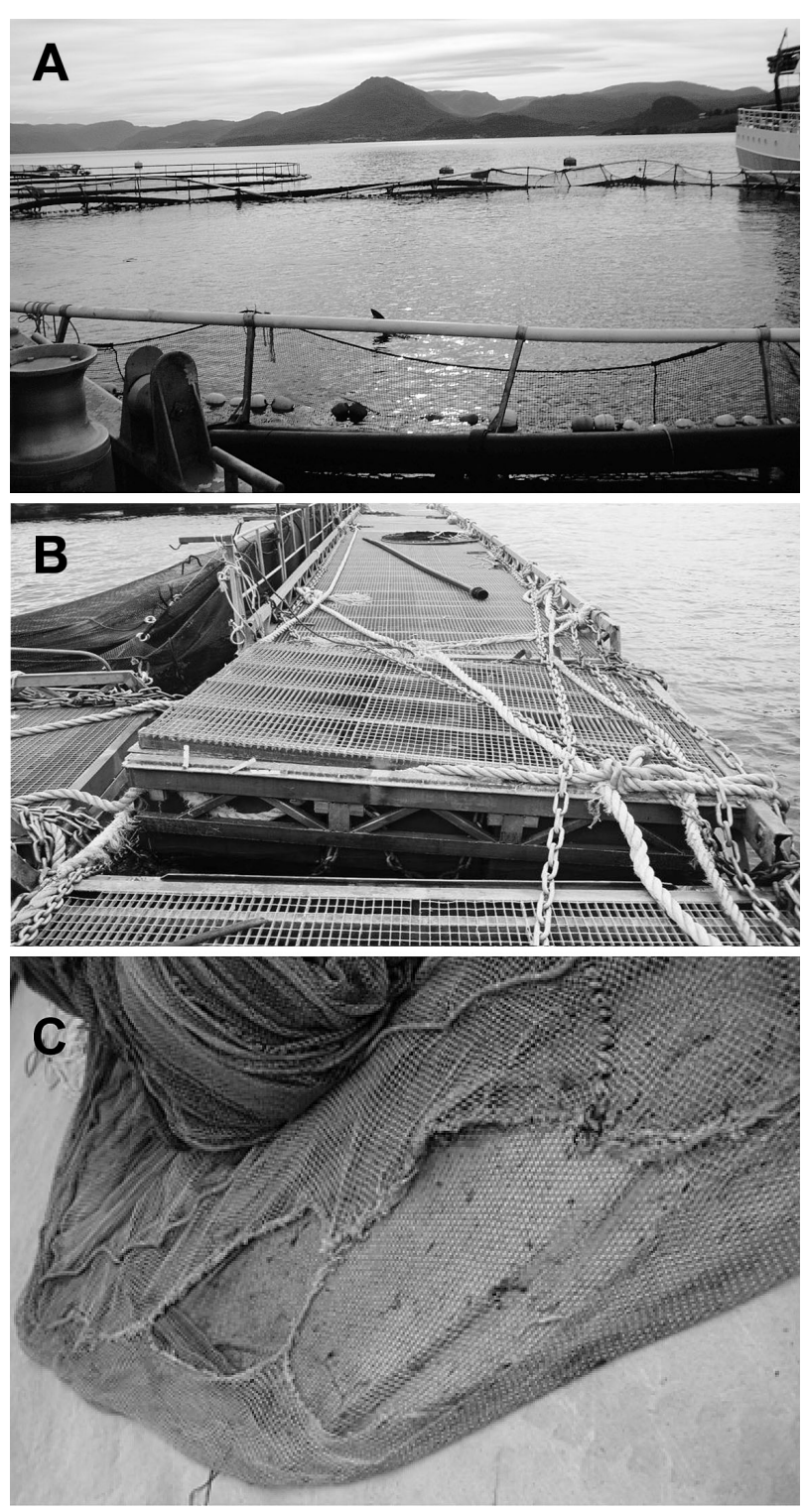

Fig. 6. Examples of the major structural causes of escape incidents: (A) progressive mooring failure; (B) breakdown and sinking of steel fish farms; and (C) abrasion and tearing of nets

\section{Breakdown and sinking of steel fish farms}

Hinged steel fish farms are popular work stations as, due to their buoyancy, they allow the use of heavy auxiliary equipment and fork lifts on the farm. Due to their construction, steel farms in general have no or limited flexibility in the horizontal plane (Fredheim \& Langan 2009). This gives rise to structural problems when exposed to short-crested irregular waves, as the waves induce forced vertical displacement of the bridges and introduce large stresses and strains in the structure. Fatigue and crack propagation in or close to the hinges often result and can lead to separation of the bridges 
(Fig. 6B) and tearing of the net. In January 2006, close to 150000 cod escaped from a fish farm in northern Norway during a storm. The fish escaped after the farm collapsed under the combined loading from wind, waves and ice (Jensen 2006). Due to forced displacement induced by the waves and ice, the farm was torn apart and the fish escaped.

\section{Abrasion and tearing of nets}

Net failure, and the subsequent formation of a hole, is by far the dominant means of reported escape for fish from Norwegian aquaculture. Approximately twothirds of reported escape incidents and number of fish escape due to holes in the nets. Multiple reasons exist for the formation of holes. Biting by predators or caged fish, abrasion, 'collisions' with boats, flotsam and cage handling procedures (e.g. lifting) are among the most common causes of holes in the nets (Fig. 6C). The trend in Norway is that fish farms are moving into areas with stronger and steadier currents in order to improve water quality. As a result, forces on the net increase and net deformation increases accordingly (Lader et al. 2008). Several large-scale escapes have occurred over the past 2 to 3 yr due to contact (and thus abrasion) between the net and the sinker tube chain (Moe 2008a,b, 2009). In one of them, more than 80000 fish escaped.

\section{ECONOMIC CONSEQUENCES TO FISH FARMERS}

Relatively little information exists on the direct costs of escapes, although the European Union's 7th Research Framework project Prevent Escape (www. preventescape.eu) is currently assessing the cost of escape to the fish farming industry across Europe, and the true cost of escapes is thus likely to be known by 2011 . In Norway, as reported escapes of salmon on average account for losses of $<0.2 \%$ of the fish held in sea-cages each year, the relative direct economic cost to the industry is small, even when the cost of replacing damaged equipment or paying for recapture efforts is accounted for. Insurance claims are likely to offset these costs (Naylor et al. 2005). This may mean that little direct economic incentive exists for salmon farmers to invest further time and resources to prevent escape events. As the percentage of cod that escape is considerably greater than that of salmon, direct economic losses are more significant (Moe et al. 2007a) and may stimulate investments in containment technologies.

The greatest cost of escape to the industry, however, is indirect, as escapes damage the industry's reputation. The popular press often report escape events widely, which sheds negative light on the industry's environmental credentials and fuels criticism from environmental groups (e.g. WWF 2005). The extent to which this restricts the industry from expanding the number of sites it uses and the amount of fish it produces is immeasurable, but is likely to be significant, as the threats that escapes pose to wild populations are strong counterpoints in debates regarding industry expansion (Naylor et al. 2005, Hindar et al. 2006). While the economic consequences of reduced production caused by escaped salmon are not known for Norway, a review of the general economic consequences of escapes to wild salmon populations is given by Naylor et al. (2005).

\section{ENVIRONMENTAL CONSEQUENCES}

Escapees can have detrimental genetic and ecological effects on populations of wild conspecifics, and the present level of escapees is regarded as a problem for the future sustainability of sea-cage aquaculture (Naylor et al. 2005). Over 325 million Atlantic salmon are held in sea-cages in Norway at any given time (Norwegian Directorate of Fisheries 2009), which outnumbers the $\sim 500000$ to 1 million salmon that return to Norwegian rivers from the ocean each year to spawn (Scientific Advisory Committee 2009). A single sea-cage may hold 100s of thousands of cultured fish, meaning that sites with multiple cages may contain more than 1 million fish. Due to the large numerical imbalances of caged compared to wild populations, escapement raises important concerns about ecological and genetic impacts. Evidence of environmental effects on wild populations is largely limited to Atlantic salmon, as these interactions have been intensively studied, with more limited information for Atlantic cod.

\section{Atlantic salmon}

In a comprehensive review of the effects of escaped Atlantic salmon on wild populations, Thorstad et al. (2008) concluded that while outcomes of escapee-wild fish interactions vary with environmental and genetic factors, they are frequently negative for wild salmon. As fish farm areas are typically located close to wild fish habitats, and escaped fish may disperse over large geographic areas (e.g. Furevik et al. 1990, Hansen 2006, Whoriskey et al. 2006, Skilbrei et al. in press), escaped salmon may mix with their wild conspecifics and enter rivers 10 s to 100 s of kilometers from the escape site during the spawning period. The average percentage of escaped salmon in Norwegian rivers monitored close to the spawning period varied between 11 and $35 \%$ during 1989 to 2008, with the highest percentages during the late 1980s and early 
1990s (Scientific Advisory Committee 2009). Consequently, the potential exists for escapees to interact negatively with wild populations, through competition, transfer of diseases and pathogens, and interbreeding.

Transfer of diseases and pathogens

Escape incidents may heighten the potential for the transfer of diseases and parasites, which are considered to be amplified in aquaculture settings (e.g. Heuch \& Mo 2001, Bjørn \& Finstad 2002, Skilbrei \& Wennevik 2006, Krkošek et al. 2007). Escapees from salmon aquaculture in Norway have been identified as reservoirs of sea lice in coastal waters (Heuch \& Mo 2001). In addition, 60000 salmon infected with infectious salmon anaemia and 115000 salmon infected with pancreas disease escaped from farms in southern Norway in 2007, yet whether these precipitated infections in wild populations is unknown. The ability for escaped fish to transfer disease to wild fish depends on the extent of mixing between the 2 groups, which in turns varies with the life stage, timing and location of the escape (summarised by Thorstad et al. 2008). However, while escaped and wild fish mix, little direct evidence for disease transfer from escapees to wild salmon populations exists, other than for the possible case of furunculosis, a fungal disease accidently introduced to Norway from Scotland in the 1990s with the transfer of stock and then believed to have been spread from farmed to wild populations by escapees (summarised by Naylor et al. 2005).

\section{Interbreeding}

Successful spawning of escaped farmed salmon in rivers both within and outside their native range has been widely documented (see review by Weir \& Grant 2005). The ability of escaped salmon to interbreed with wild salmon depends on their ability to ascend rivers, access spawning grounds and spawn successfully with wild partners. While the spawning success of farmed female salmon may be just 20 to $40 \%$ that of wild salmon and even lower for males (1 to $24 \%$; Fleming et al. 1996, 2000), high percentages of escaped fish in many rivers can lead to a high percentage of farm $\times$ wild hybrids. Escaped female salmon may also interfere with wild salmon breeding through the destruction of spawning redds of wild fish due to later spawning (Lura \& Sæegrov 1991, 1993).

Wild Atlantic salmon are structured into populations and meta-populations with little gene flow between them, and evidence for local adaptation in wild Atlantic salmon is compelling (reviewed by Garcia de Leaniz et al. 2007). Farmed salmon differ genetically from wild populations due to founder effects, domestication selection, selection for economic traits and genetic drift (reviewed by Ferguson et al. 2007). Hybridisation of farmed with wild salmon and later backcrossing of hybrids may change the level of genetic variability and the frequency and type of alleles present. Hence, hybridisation of farmed with wild salmon has the potential to genetically alter native populations, reduce local adaptation and negatively affect population viability and character (Ferguson et al. 2007). Several studies have shown that escaped farmed salmon breeding in the wild have changed the genetic composition of wild populations (e.g. Clifford et al. 1998, Skaala et al. 2006). Hindar \& Diserud (2007) recommended that intrusion rates of escaped farmed salmon in rivers during spawning should not exceed $5 \%$ to avoid substantial and definite genetic changes of wild populations.

Large-scale field experiments undertaken in Norway and Ireland showed highly reduced survival and lifetime success of farm and hybrid salmon compared to wild salmon (McGinnity et al. 1997, 2003, Fleming et al. 2000). The relative estimated lifetime success ranged from lowest for the farm progeny to highest for the local wild progeny with intermediate performance for the hybrids. Farmed salmon progeny and farm $\times$ wild hybrids may directly interact and compete with wild juveniles for food, habitat and territories. Farm juveniles and hybrids are generally more aggressive and consume similar resources in freshwater habitats as wild fish (Einum \& Fleming 1997). In addition, they grow faster than wild fish, which may give them a competitive advantage during certain life stages. Invasions of escaped farmed salmon have the potential to impact the productivity of wild salmon populations negatively through juvenile resource competition and competitive displacement. Fleming et al. (2000) determined that invasion of a small river in Norway by escapees resulted in an overall reduction in smolt production by $28 \%$ due to resource competition and competitive displacement. Local fisheries could therefore suffer reduced catches as wild fish stocks decline (Svåsand et al. 2007).

\section{Competition for food}

Escaped salmon consume much the same diet as wild salmon in oceanic waters (Hislop \& Webb 1992, Jacobsen \& Hansen 2001) and could potentially compete for food with wild stocks. Substantial competitive interactions in the ocean, however, appear unlikely to occur, as ocean mortality of salmon appears to be density-independent (Jonsson \& Jonsson 2004), although limited information exists to assess if this is also the case for coastal waters (Jonsson \& Jonsson 2006). 


\section{Atlantic cod}

At present, little direct evidence exists for negative interactions of escaped and wild Atlantic cod juveniles or adults, despite predictions that negative consequences will result (Bekkevold et al. 2006). Cod farming is a relatively new industry; thus if negative consequences exist, they may not have had sufficient time to manifest and/or be detected. Telemetry studies of simulated cod escapes have indicated that escapees, regardless of whether they originated from stocks of coastal or oceanic origin, mix with wild populations in fjord environments and can move to spawning grounds in the spawning season (Uglem et al. 2008, 2010). Behavioural studies have further indicated that escaped farmed cod are likely to hybridise with wild cod (Meager et al. 2009). However, farmed cod may have limited reproductive success in sperm competition with wild cod, which lowers the risk of genetic introgression from escapees (Skjæraasen et al. 2009). Further, they may occupy different strata in the water column at breeding time relative to wild cod (Meager et al. 2009).

Other possible ecological effects of escaped farmed cod include increased predation pressure on outmigrating wild salmon smolt (Brooking et al. 2006) and transmission of pathogens and parasites to wild populations (Øines et al. 2006), although direct evidence for these effects is at present lacking. Recaptures of Atlantic cod escapees equipped with acoustic transmitters in local commercial and recreational fisheries in Norway are high ( 40\%; Uglem et al. 2008), indicating that local fisheries receive temporary increases after escape events and may be partially effective in reducing escaped cod numbers.

\section{'Escape through spawning' of Atlantic cod}

In the culture of Atlantic cod, some fish mature during the first year of culture, while a majority of farmed cod are believed to mature during the second year. This means that almost the entire culture stock in any particular farm has the potential to spawn in sea-cages before they are slaughtered. Spawning of Atlantic cod within a small experimental sea-cage containing 1000 farmed cod and dispersal of their spawned eggs up to $10 \mathrm{~km}$ away in a fjord system has been demonstrated (Jørstad et al. 2008). In the proximity of this experimental sea-cage, 20 to $25 \%$ of the cod larvae in plankton samples were determined by genetic analyses to have originated from the 1000 farmed cod (Jørstad et al. 2008). Furthermore, preliminary results indicate that 4 to $6 \%$ of juvenile cod ( 35 to $40 \mathrm{~cm}$ total length) caught in the area around the farm in following years were offspring of the farmed cod (van der Meeren \& Jørstad 2009). This illustrates that if spawning occurs within commercial cod farms where numbers of farmed individuals are far greater, the contribution of 'escaped' larvae to cod recruitment within fjord systems may be substantial.

Escape of large quantities of eggs from caged cod could lead to ecological and genetic effects in wild populations (Bekkevold et al. 2006, Jørstad et al. 2008), as (1) coastal cod populations in some areas of Norway are presently weak, most likely due to overfishing (ICES 2008); (2) coastal cod have a high fidelity to specific spawning grounds (e.g. Wright et al. 2006); and (3) sea-cage cod farms are often located within short distances of known wild cod spawning grounds (Uglem et al. 2008). Recent research also suggests that cod eggs may be entrained in the vicinity of the spawning grounds long after spawning (Knutsen et al. 2007). Therefore, there is considerable potential for larvae from escaped cod eggs to experience favourable conditions for survival and recruitment to coastal cod stocks if spawning in sea-cages occurs during the natural spawning season of wild cod.

\section{PREVENTING ESCAPES: THE NORWEGIAN EXPERIENCE}

\section{Adult fishes}

Over the past decade, Norway has established a range of processes and tools to deal with the problem of escapes. These include: (1) mandatory reporting of all escape incidents; (2) establishment of the Norwegian Escapes Commission to learn from past escape events and disseminate knowledge to both fish farmers and aquaculture equipment suppliers; (3) introducing enforceable technical regulations for the design, dimensioning, installation and operation of sea-cage farms; (4) ongoing investment in research and development projects to improve the design and material properties of sea-cage equipment; and (5) training of fish farm operators in the different aspects of why and how to prevent escapes. Here, we detail these efforts, describe their effect on dealing with the escapement issue, and discuss improvements that can be made.

\section{Mandatory reporting}

Mandatory reporting of escape incidents was introduced by Norway in the 1980s, with a national statistics database established in 2001. This has enabled: (1) assessment of the overall status of the escapes problem at an industry-wide scale from year to year (e.g. Fig. 1); 
(2) assessment of the causes of escapes (e.g. Fig. 3); and (3) efforts to recapture escapees to be made. Without this basic process in place, coordinated action to deal with escapes is unlikely because the scale of the problem cannot be estimated. Establishing that escapes are of sufficient magnitude to have an ecological impact will drive mechanisms for change in practices or regulations. However, while mandatory reporting does provide useful, general information, understanding the detailed causes of escapes requires different processes. In addition, an evaluation of the percentage of real losses reported through such a mandatory reporting system should be performed, both in Norway and elsewhere. To be able to fully evaluate the causes for escapes, the percentage of unreported escapes, and the reasons for these escapes, should also be known.

\section{Norwegian Aquaculture Escapes Commission (AEC)}

Official statistics collated from mandatory reporting and other sources of information which apportion causality to escape events typically provide little explicit detail to support technological development to improve farming equipment and modify operations to avoid mistakes that cause escapes. Categorisation of causes from mandatory reporting forms may also be inaccurate, as causes are rarely investigated in detail by individual farmers (Valland 2005). Such detail only comes through careful investigation of the causes of escape incidents on a case-by-case basis. For example, Jensen (2006) visited 8 fish farms in northern Norway after 2 severe storms in January 2006 caused damage to numerous farms in the region. While 'storm' was listed as the official cause of these escapes, the specific circumstances behind each event varied widely. Storms may damage surface floaters, tear nets through net deformation or rubbing of the nets on net weights in the strong currents they generate, and overload the mooring structures that hold the farm in place. At a smaller scale, an understanding of how individual components perform in the mooring system (such as anchors, shackles, ropes, bolts and mooring coupling plates), the cage system (net material, cage ropes and cage weights) and the steel platform or polyethylene floaters is crucial to ensure each element is engineered to match the particular characteristics of each farm type and location.

To meet the challenge of more accurately determining causes of escapes, the Norwegian government established the AEC in September 2006. Since its establishment, the AEC has compiled data on all reported escape occurrences in Norway and has a mandate to conduct more thorough investigations of individual escape events when required. The AEC disseminates information to manufacturers of fish farming equipment when improvements have been identified, and may issue warnings to fish farmers regarding the use of specific sea-cage technologies.

\section{Norwegian technical standard (NS 9415)}

The Norwegian technical standard NS 9415 (Marine fish farms: requirements for site survey, risk analyses, design, dimensioning, production, installation and operation regulations; Standard Norge 2009) was implemented through Norwegian legislation on 1 April 2004 and introduced requirements for the technical standard of marine fish farms in Norwegian waters. NS 9415 specifies requirements for the design of feed barges, floaters, net cages and mooring systems necessary to cope with environmental forces (e.g. wind, waves, currents) at fish farm sites and the handling and use of equipment. From 1 April 2004, the main components (floater, net cage, feed barge and mooring system) of new farms must be independently certified against the standard. In addition, farming sites needed to be classified (wind, waves and current conditions) with 10 and 50 yr return periods. For existing farms and equipment in use before 1 April 2004, there is a transitional system which began to take effect on 1 January 2006 and runs until 2012.

Specially accredited independent companies assess the fish farms, carry out mooring and other technical analyses and use these data to evaluate the capability of the fish farm to meet the requirements of NS 9415 and to withstand the environmental forces at the specific fish farm site. If the equipment is proven capable for the site, the fish farm will receive a certificate stating proof of capability. This proof of capability is valid for up to $3 \mathrm{yr}$ and can be reissued repeatedly until 2012. From 2012, all the main components of a fish farm have to be certified. A revision occurred in 2009 and resulted in significant strengthening of the NS 9415 standard.

As an immediate result of introduction of NS 9415 in 2004, several farms replaced their existing equipment in the 2 to 3 following years, and all new equipment acquired post-2004 had to be independently certified as per the standard. This appears to have precipitated a dramatic reduction in the number of major escape incidents in Norway (Fig. 1), although with a time lag of several years after the standard was introduced, as old equipment was gradually replaced with new. Since the last major escape events in 2005 and 2006, the number of reported escaped salmon has been significantly reduced both in terms of the total number of escapees and as a percentage of the stocked number of salmon in sea-cages. This reduction is principally due 
to a sharp decline in large-scale escapes resulting from the full breakdown of whole cages or whole fish farms when floaters and/or mooring systems fail. Such failures are becoming increasingly uncommon as the NS 9415 standard is modified and strengthened over time.

Research and development to make equipment more robust

Development of the NS 9415 standard has been informed by a significant amount of industrial research to improve the materials, structures and designs of sea-cage farms (e.g. Fredheim 2005, Jensen 2005, 2006, Jensen \& Lien 2005a,b, Lien \& Jensen 2005, Moe et al. 2005, 2007a,b, 2009a,b, Lader \& Fredheim 2006, Lader et al. $2007,2008)$. This research has come about through significant investments by the Norwegian Research Council and the Norwegian Fishery and Aquaculture Industry Research Fund (e.g. SIKTEK, IntelliStruct, SECURE, CodNet, CodNet2 and WaveNet projects) and recently the European Union's 7th Research Framework (e.g. Prevent Escape project; www.preventescape.eu).

\section{Training}

As a relatively large portion of the reported escape incidents are either due to operational errors or to operations damaging equipment and thus leading to escapes, an increased focus on how operations are performed is appropriate. Some farming companies have good and well documented systems for training and education of employees, but in general, more focus is necessary. Fish farming is a complicated multi-disciplinary activity in which expertise on several different topics is required. So far, education has focused mainly on the biological aspects of farming, with comparatively less attention given to the more technical aspects.

To address this gap, several times a year the Norwegian Seafood Federation (FHL) arranges voluntary antiescape workshops which are attended by fish farmers, technology producers, the Norwegian Fisheries Directorate and accredited aquaculture equipment certification companies. Technical aspects of the workshops are often led by industrial engineers from SINTEF Fisheries and Aquaculture. Typical topics for the workshops are information about regulations, escape causes and practical measures to prevent escapes.

\section{Atlantic cod eggs}

At present, the culture of Atlantic cod in sea-cages in Norway is a relatively new activity of limited size com- pared to the large Atlantic salmon industry. Further, the possibility that escaped fertilised eggs may have genetic and ecological effects on wild populations has only recently been recognised (Jørstad et al. 2008). Much remains to be documented before the likely importance of this effect is known.

Measures to prevent the escape of fertilised eggs from sea-cages are in the research and development phase. Mechanical methods of removal, such as filtration, are unlikely to prove practical or affordable at the scale of modern cod farming. Halting sexual maturation through manipulation of the light regime in seacages has been trialled with some success, but it is difficult to inhibit maturation completely (e.g. Karlsen et al. 2006, Taranger et al. 2006) as natural light levels may override artificial lights during the daytime, thus reducing the efficacy of artificial light regimes. Hybridisation, sterilisation and polyploidy (e.g. Feindel et al. 2010) are possible alternate strategies, but higher initial mortality, greater fingerling costs, poorer growth and uncertainty about consumer acceptance mean that these techniques are not preferred by the industry (Triantafyllidis 2007). As no clear solution exists, investigating techniques to stop cod from spawning in seacages remains a research and development priority for Norwegian aquaculture.

\section{RECOMMENDED ACTIONS}

Based on the Norwegian experience of dealing with the escapes problem, we recommend a range of measures for other countries to introduce effective antiescape measures. Essentially, many of the components of the strategy to tackle escapes already in place in Norway can be directly transferred to industries in other countries. We outline these principles below in 5 steps, and discuss how some of these measures may also be improved within Norway:

1. Mandatory reporting of all escape events, including: (1) the number of fish that escaped and their size; (2) a description of the sea-cage technology involved; (3) categorisation of the operational circumstances or environmental conditions at the time of escape; and (4) an estimated cause of escape.

2. A defined mechanism to collect, analyse and learn from the mandatory reporting. This information must then be effectively disseminated to equipment suppliers and fish farmers so improvements can be made. Within Norway, the AEC has this role, although the formation of a full commission to achieve this may not be necessary in other countries.

3. As causes of escapes estimated by farmers are often inaccurate, we recommend mandatory, technical assessments to determine the causes of 'large-scale' 
escape incidents. Based on escape statistics in Norway, 'large-scale' escape events can be considered to be those that cause the loss of more than 10000 fish. The technical assessment must occur rapidly (within $48 \mathrm{~h}$ ) after the escape event. At present, no mechanism for this is in place in Norway. When technical assessments are made, they are often done weeks to months after the incident. This can lead to a loss of evidence, often making the root cause difficult to ascertain. Learning from each large-scale escape event would assist recommendations for the design and properties of seacage systems and help improve technical standards.

4. Introduction of a technical standard for sea-cage aquaculture equipment coupled with an independent mechanism to enforce the standard. Within Norway, the highly detailed NS 9415 technical standard has perhaps been the most useful tool at an industry-wide scale to prevent escapes. Voluntary standards are unlikely to be effective; therefore, we recommend enforcement through legislation. Within the next few years, NS 9415 is likely to be developed into an international standard (ISO), which will facilitate implementation in sea-cage industries worldwide.

5. Certain operations within fish farming (e.g. correct anchoring and mooring, connecting net-cages to floaters and correct weighting of net-cages in currents) are likely to pose a higher risk of an escape event occurring if they are done incorrectly. Therefore, these key processes should be identified, and mandatory training of staff who undertake these processes would likely reduce human errors that lead to escapes. Many other industries have similar mandatory training requirements for operators to perform particular tasks, and thus legislative precedents would likely exist in most countries that could be drawn upon.

Acknowledgements. We thank the Norwegian Directorate of Fisheries and the Norwegian Aquaculture Escape Commission (AEC) for providing data and Fig. 6B. Funding was provided by the European Union's 7th Research Framework to the Prevent Escape project (no. 226885) and by the Norwegian Research Council's 'Havbruk' programme to the Secure project (no. 184974/S40).

\section{LITERATURE CITED}

Bekkevold D, Hansen MM, Nielsen EE (2006) Genetic impact of gadoid culture on wild fish populations: predictions, lessons from salmonids, and possibilities for minimizing adverse effects. ICES J Mar Sci 63:198-208

Bjørn PA, Finstad B (2002) Salmon lice, Lepeophtheirus salmonis (Krøyer), infestation in sympatric populations of Arctic char, Salvelinus alpinus (L.), and sea trout, Salmo trutta (L.), in areas near and distant from salmon farms. ICES J Mar Sci 59:131-139

Brooking P, Doucette G, Tinker S, Whoriskey FG (2006) Sonic tracking of wild cod, Gadus morhua, in an inshore region of the Bay of Fundy: a contribution to understanding the impact of cod farming for wild cod and endangered salmon populations. ICES J Mar Sci 63:1364-1371

Clifford SL, McGinnity P, Ferguson A (1998) Genetic changes in Atlantic salmon (Salmo salar) populations of northwest Irish rivers resulting from escapes of adult farm salmon. Can J Fish Aquat Sci 55:358-363

> Einum S, Fleming IA (1997) Genetic divergence and interactions in the wild among native, farmed and hybrid Atlantic salmon. J Fish Biol 50:634-651

Feindel N, Benfey T, Trippel E (2010) Competitive spawning success and fertility of triploid male Atlantic cod (Gadus morhua). Aquacult Environ Interact 1:47-55

Ferguson A, Fleming I, Hindar K, Skaala Ø, McGinnity P, Cross TF, Prodöhl P (2007) Farm escapes. In: Verspoor E, Stradmeyer L, Nielsen JL (eds) The Atlantic salmon: genetics, conservation and management. Blackwell Publishing Ltd, Oxford, p 357-398

Fiske P, Lund RA, Hansen LP (2006) Relationships between the frequency of farmed Atlantic salmon, Salmo salar L., in wild salmon populations and fish farming activity in Norway, 1989-2004. ICES J Mar Sci 63:1182-1189

> Fleming IA, Jonsson B, Gross MR, Lamberg A (1996) An experimental study of the reproductive behaviour and success of farmed and wild salmon (Salmo salar). J Appl Ecol 33:893-905

Fleming IA, Hindar K, Mjølnerød IB, Jonsson B, Balstad T, Lamberg A (2000) Lifetime success and interactions of farm salmon invading a native population. Proc Biol Sci 267:1517-1523

Fredheim A (2005) Current forces on net structures. PhD thesis, Norwegian University of Science and Technology (NTNU), Trondheim

Fredheim A, Langan R (2009) Advances in technology for offshore and open ocean aquaculture. In: Burnell G, Allen G (eds) New technologies in aquaculture: improving production efficiency, quality and environmental management. Woodhead Publications, Cambridge, p 914-944

Furevik D, Rabben H, Mikkelsen KO, Fosseidengen JE (1990) Migratory patterns of escaped farm-raised Atlantic salmon. ICES CM 1990/F:55. ICES, Copenhagen

Garcia de Leaniz C, Fleming IA, Einum S, Verspoor E and others (2007) A critical review of inherited adaptive variation in Atlantic salmon. Biol Rev Camb Philos Soc 82: 173-211

Gillanders BM, Joyce TC (2005) Distinguishing aquaculture and wild yellowtail kingfish via natural elemental signatures in otoliths. Mar Freshw Res 56:693-704

Glover KA (2010) Forensic identification of fish farm escapees: the Norwegian experience. Aquacult Environ Interact 1:1-10

> Hansen LP (2006) Migration and survival of farmed Atlantic salmon (Salmo salar L.) released from two Norwegian fish farms. ICES J Mar Sci 63:1211-1217

> Hansen LA, Dale T, Uglem I, Aas K, Damsgård B, Bjørn PA (2008) Escape related behaviour of Atlantic cod (Gadus morhua L.) in a simulated farm situation. Aquac Res 40: 26-34

> Heuch PA, Mo TA (2001) A model of salmon louse production in Norway: effects of increasing salmon production and public management measures. Dis Aquat Org 45:145-152

Hindar K, Diserud O (2007) Vulnerability analysis of wild salmon populations towards escaped farm salmon. Nor Inst Nat Res Rep 244:1-45 (In Norwegian with English summary)

> Hindar K, Fleming IA, McGinnity P, Diserud O (2006) The genetic and ecological effects of salmon farming on wild salmon: modelling from experimental results. ICES J Mar Sci 63:1234-1247 
Hislop JRG, Webb JH (1992) Escaped farmed Atlantic salmon (Salmo salar) feeding in Scottish coastal waters. Aquacult Fish Manag 23:721-723

ICES (2008) Report of the ICES Advisory Committee, 2008. Book 6, North Sea. ICES, Copenhagen

> Jacobsen JA, Hansen LP (2001) Feeding habits of wild and escaped farmed Atlantic salmon, Salmo salar L., in the Northeast Atlantic. ICES J Mar Sci 58:916-933

Jensen $\varnothing$ (2005) Ice loads - ice growth and suggestions for measures. Report no. SFH80 A064062. SINTEF, Trondheim (in Norwegian)

Jensen $\varnothing$ (2006) Assessment of technical requirements for floating fish farms - based on escape incidents January 2006. Rep no SFH80 A066056. SINTEF, Trondheim (in Norwegian)

Jensen $\varnothing$, Lien E (2005a) Risk — design loads and safety. Rep no SFH80 A064059. SINTEF, Trondheim (in Norwegian)

Jensen Ø, Lien E (2005b) Environmental loads at sites. Rep no SFH80 A064058. SINTEF, Trondheim (in Norwegian)

$>$ Jonsson B, Jonsson N (2004) Factors affecting marine production of Atlantic salmon (Salmo salar). Can J Fish Aquat Sci 61:2369-2383

> Jonsson B, Jonsson N (2006) Cultured Atlantic salmon in nature: a review of their ecology and interaction with wild fish. ICES J Mar Sci 63:1162-1181

Jørstad KE, van der Meeren T, Paulsen OI, Thomsen T, Thorsen A, Svåsand T (2008) 'Escapes' of eggs from farmed cod spawning in net pens: recruitment to wild stocks. Rev Fish Sci 16:285-295

Karlsen Ø, Norberg B, Kjesbu OS, Taranger GL (2006) Effects of photoperiod and exercise on growth, liver size, and age at puberty in farmed Atlantic cod (Gadus morhua L.). ICES J Mar Sci 63:355-364

Kjønhaug AF (2009) Production figures for salmon and rainbow trout 2008. Kyst og Havbruk 2009:128-130 (in Norwegian)

Knutsen H, Moland OE, Ciannelli L, Heiberg ES, Knutsen JA, Simonsen JH, Skreslet S, Stenseth NC (2007) Egg distribution, bottom topography and small-scale cod population structure in a coastal marine system. Mar Ecol Prog Ser 333:249-255

Krkošek M, Ford JS, Morton A, Lele S, Myers RA, Lewis MA (2007) Declining wild salmon populations in relation to parasites from farm salmon. Science 318:1772-1775

Lader PF, Fredheim A (2006) Dynamic properties of a flexible net sheet in waves and current-a numerical approach. Aquac Eng 35:228-238

Lader PF, Olsen A, Jensen A, Sveen JK, Fredheim A, Enerhaug B (2007) Experimental investigation of the interaction between waves and net structures-damping mechanism. Aquac Eng 37:100-114

> Lader P, Dempster T, Fredheim A, Jensen Ø (2008) Current induced net deformations in full-scale sea-cages for Atlantic salmon (Salmo salar). Aquac Eng 38:52-65

Lien E, Jensen $\varnothing$ (2005) Interaction - total systems. Rep no SFH80 A064060. SINTEF, Trondheim (in Norwegian)

> Lura H, Sægrov H (1991) Documentation of successful spawning of escaped farmed female Atlantic salmon, Salmo salar, in Norwegian rivers. Aquaculture 98:151-159

Lura H, Sægrov H (1993) Timing of spawning in cultured and wild Atlantic salmon (Salmo salar) and brown trout (Salmo trutta) in the River Vosso, Norway. Ecol Freshw Fish 2: 167-172

McGinnity P, Stone C, Taggart JB, Cooke D and others (1997) Genetic impact of escaped farmed Atlantic salmon (Salmo salar L.) on native populations: use of DNA profiling to assess freshwater performance of wild, farmed, and hybrid progeny in a natural river environment. ICES J Mar Sci 54:998-1008

McGinnity P, Prodohl P, Ferguson K, Hynes R and others (2003) Fitness reduction and potential extinction of wild populations of Atlantic salmon, Salmo salar, as a result of interactions with escaped farm salmon. Proc Biol Sci 270: $2443-2450$

Meager JJ, Skjæraasen JE, Fernö A, Karlse Ø, Løkkeborg S, Michalsen K, Utskot SO (2009) Vertical dynamics and reproductive behaviour of farmed and wild Atlantic cod Gadus morhua. Mar Ecol Prog Ser 389:233-243

Moe H (2008a) Inspection of net cages - assessment of condition and possible causes of damage. The Norwegian Aquaculture Escapes Commission, Bergen. Available at: www.rommingskommisjonen.no/uploads/sintefrappnot070109.pdf (accessed 6 Aug 2010) (in Norwegian)

Moe H (2008b) Inspection of net cages at Austevoll - assessment of condition and possible causes of damage. The Norwegian Aquaculture Escapes Commission, Bergen. Available at: www.rommingskommisjonen.no/uploads/ sintefrappnot-200209.pdf (accessed 6 Aug 2010) (in Norwegian)

Moe H (2009) Inspection of net cages for the Aquaculture Escape Commission - assessment of condition and possible causes of damage. The Norwegian Aquaculture Escapes Commission, Bergen. Available at: www. rommingskommisjonen.no/uploads/sintefrappnot-240409. pdf (accessed 6 Aug 2010) (in Norwegian)

Moe H, Gaarder R, Sunde LM, Borthen J, Olafsen K (2005) Escape-free net cages for cod. Report no. SFH A 054041, SINTEF, Trondheim

- Moe H, Dempster T, Sunde LM, Winther U, Fredheim A (2007a) Technological solutions and operational measures to prevent escapes of Atlantic cod (Gadus morhua) from sea-cages. Aquac Res 38:91-99

> Moe H, Olsen A, Hopperstad OS, Jensen $\varnothing$, Fredheim A (2007b) Tensile properties for netting materials used in aquaculture net cages. Aquac Eng 37:252-265

> Moe H, Gaarder RH, Olsen A, Hopperstad OS (2009a) Resistance of aquaculture net cage materials to biting by Atlantic Cod (Gadus morhua). Aquac Eng 40:126-134

Moe H, Hopperstad OS, Olsen A, Jensen Ø, Fredheim A (2009b) Temporary-creep and post-creep properties of aquaculture netting materials. Ocean Eng 36:992-1002

Naylor R, Hindar K, Fleming IA, Goldburg R and others (2005) Fugitive salmon: assessing the risks of escaped fish from net-pen aquaculture. Bioscience 55:427-437

Norwegian Directorate of Fisheries (2009) Statistics for Aquaculture 2008. Norwegian Directorate of Fisheries, Bergen. Available at: www.fiskeridir.no/fiskeridir/kystsone_og_ havbruk/statistikk (accessed 6 Aug 2010) (in Norwegian)

Norwegian Ministry of Fisheries and Coastal Affairs (2008). Aquaculture operations regulations with remarks. Norwegian Ministry of Fisheries and Coastal Affairs, Bergen. Available at: http://www.lovdata.no/cgi-wift/ldles?doc=/ sf/sf/sf-20080617-0822.html (in Norwegian)

Øines Ø, Simonsen JH, Knutsen JA, Heuch PA (2006) Host preference of adult Caligus elongatus Nordmann in the laboratory and its implications for Atlantic cod aquaculture. J Fish Dis 29:167-174

Oppedal F, Dempster T, Stien L (in press) Environmental drivers of Atlantic salmon behaviour in sea-cages: a review. Aquaculture

Scientific Advisory Committee (2009) The status of Norwegian salmon stocks in 2009 and catch advice. Report from the Scientific Advisory Committee for Atlantic Salmon Management in Norway No. 1. Vitenskapelig råd for 
lakseforvaltning, Trondheim (In Norwegian with English summary)

Skaala Ø, Wennevik V, Glover KA (2006) Evidence of temporal genetic change in wild Atlantic salmon, Salmo salar L., populations affected by farm escapees. ICES J Mar Sci 63: $1224-1233$

Skilbrei O, Holst JC, Asplin L, Mortensen S (in press) Horizontal movements of simulated escaped farmed Atlantic salmon (Salmo salar) in a western Norwegian fjord. ICES J Mar Sci doi:10.1093/icesjms/fsq027

Skilbrei O, Wennevik V (2006) Survival and growth of searanched Atlantic salmon, Salmo salar L., treated against sea lice before release. ICES J Mar Sci 63:1317-1325

Skjæraasen JE, Mayer I, Meager JJ, Rudolfsen G, Karlsen Ø, Haugland T, Kleven O (2009) Sperm characteristics and competitive ability in farmed and wild cod. Mar Ecol Prog Ser 375:219-228

Soto D, Jara F, Moreno C (2001) Escaped salmon in the inner seas, southern Chile: facing ecological and social conflicts. Ecol Appl 11:1750-1762

Standard Norge (2009) Norwegian standard NS 9415.E:2009 Marine fish farms - requirements for site survey, risk analyses, design, dimensioning, production, installation and operation. Standard Norge, Lysaker

Svåsand T, Crosetti D, García-Vázquez E, Verspoor E (eds) (2007) Genimpact - evaluation of genetic impact of aquaculture activities on native populations. Final scientific report, EU contract no. RICA-CT-2005-022802. Available at: http://genimpact.imr.no/_data/page/7649/genetic_ impact_of_aquaculture.pdf (accessed 6 Aug 2010)

Taranger GL, Aardal L, Hansen T, Kjesbu OS (2006) Continuous light delays sexual maturation and increases growth of Atlantic cod (Gadus morhua L.) in sea cages. ICES J Mar Sci 63:365-375

Thorstad EB, Fleming IA, McGinnity P, Soto D, Wennevik V, Whoriskey $F$ (2008) Incidence and impacts of escaped farmed Atlantic salmon Salmo salar in nature. Nor Inst Nat Res Spec Rep 36:1-110

Toledo Guedes K, Sanchez-Jerez P, Gonzalez-Lorenzo G, Brito Hernandez A (2009) Detecting the degree of estab-

Editorial responsibility: Pablo Sánchez-Jerez,

Alicante, Spain lishment of a non-indigenous species in coastal ecosystems: sea bass Dicentrarchus labrax escapes from sea cages in Canary Islands (Northeastern Central Atlantic). Hydrobiologia 623:203-212

Torrissen OJ (2007) Status report for Norwegian aquaculture 2007. Kyst og Havbruk 2007: 11-12 (in Norwegian)

Triantafyllidis A (2007) Aquaculture escapes: new DNA based monitoring analysis and application on sea bass and sea bream. CIESM Workshop Monogr 32:67-71

Uglem I, Bjørn PA, Dale T, Kerwath S and others (2008) Movements and spatiotemporal distribution of escaped farmed and local wild Atlantic cod (Gadus morhua L.). Aquac Res 39:158-170

Uglem I, Bjørn PA, Mitamura H, Nilsen R (2010) Spatiotemporal distribution of coastal and oceanic Atlantic cod (Gadus morhua L.) sub-groups after escape from a farm. Aquacult Environ Interact 1:11-20

Valland A (2005) The causes and scale of escapes from salmon farming. In: Hansen LP, Windsor M (eds) Interactions between aquaculture and wild stocks of Atlantic salmon and other diadromous fish species: science and management, challenges and solutions. NINA Special Report 34. Norwegian Institute for Nature Research (NINA), Trondheim, p 29

van der Meeren T, Jørstad K (2009) Fanger torsk på vidvanke. Nytt fra havbruk 2009(2):1

Weir LK, Grant JWA (2005) Effects of aquaculture on wild fish populations: a synthesis of data. Environ Res 13: 145-168

Whoriskey FG, Brooking P, Doucette G, Tinker S, Carr JW (2006) Movements and survival of sonically tagged farmed Atlantic salmon released in Cobscook Bay, Maine, USA. ICES J Mar Sci 63:1218-1223

Wright PJ, Galley E, Gibb IM, Neat FC (2006) Fidelity of adult cod to spawning grounds in Scottish waters. Fish Res 77: 148-158

WWF (2005) On the run - escaped farmed salmon in Norwegian waters. WWF-Norway Rep 2/2005. WWF-Norway, Oslo. Available at: http://wwf.no/dette_jobber_med/hav_ og_kyst/akvakultur/romt_fisk_og_introduserte_arter/ (accessed 6 Aug 2010)

Submitted: April 30, 2010; Accepted: July 23, 2010

Proofs received from author(s): August 9, 2010 